\title{
Soil preparation and NPK fertilization in the planting of five Atlantic Rainforest species in a clay extraction area
}

\author{
Ana Paula Braido Pinheiro I; Adriele dos Santos Jardim II; João Vitor Garcia Silva III; \\ Adriano Alves Fernandes ${ }^{\text {V; }}$; Fábio Ribeiro Pires v; Luis Fernandes Tavares de Menezes v;; \\ Edilson Romais Schmildt VII; Frederico Santos Machado VIII
}

\begin{abstract}
The occurrence of degraded areas worldwide grows each year and measures must be taken to mitigate degradation and to recover these areas. The aim of this study was to assess the effect of soil preparation and NPK levels on the growth of five native species of the Atlantic Rainforest in clay extraction area. The experimental design was randomized block in a split-split plot arrangement with four replications. Subsoiling and scarification soil preparation represented main plots. Doses of NPK 04-14-08: $0 ; 40 ; 80 ; 160$; and 320 $\mathrm{g} \mathrm{pit}^{-1}$ represented subplots and Atlantic Rainforest native species represented subsubplots. Absolute growth rate, stem diameter and number of leaves were evaluated, 210 days after planting. The type of soil preparation did not influence the development of the species. The best dose for Dalbergia ecastaphyllum, Inga laurina, Protium heptaphyllum and Psidium cattleyanum were 176.49, 150.18, 199.25 and $166.48 \mathrm{~g} \mathrm{pit}^{-1}$ of NPK, respectively. Schinus terebinthifolius was highly responsive to planting fertilization, being recommended $320 \mathrm{~g} \mathrm{pit}^{-1}$ of NPK. All species are indicated for area recovery.
\end{abstract}

Keywords: Chemical fertilization; Revegetation; Oil and natural gas.

\footnotetext{
I Federal University of Espírito Santo, São Mateus, ES, Brazil. anabraidop@gmail.com

II Federal University of Espírito Santo, São Mateus, ES, Brazil. dricajardim23@hotmail.com

${ }^{\text {III }}$ Federal University of Espírito Santo, São Mateus, ES, Brazil. joao_vitorgarcia@hotmail.com

IV Federal University of Espírito Santo, São Mateus, ES, Brazil. afernandesufes@gmail.com

$v^{v}$ Federal University of Espírito Santo, São Mateus, ES, Brazil. pires.fr@gmail.com

vi Federal University of Espírito Santo, São Mateus, ES, Brazil. e.romais.s@gmail.com

VII Federal University of Espírito Santo, São Mateus, ES, Brazil. edilson.schmildt@ufes.br

viII Petrobras Research Center, Rio de Janeiro, Brazil. fredericomachado@petrobras.com.br
} 


\section{INTRODUCTION}

The concern with natural resource and environmental preservation is notorious nowadays, given the demand for sustainable development, searching for balance among economic, environmental and social matters. Despite the strict precaution norms adopted, companies that exploit non-renewable natural resources, may cause negative impacts for the environment.

The occurrence of degraded areas in the world is growing and this is not different in Brazil. Extensive areas are found degraded basically due to anthropic activities resulting from the exploitation of natural resources, causing the removal of the fertile topsoil and the exposition of low fertility horizons (REIS, 2006; MACHADO et al. 2013). According to Oliveira and Souto (2011), this kind of degradation is more severe, creating environmental, political, cultural, social, and economic impacts.

Among the environmental impacts is the removal of the fertile soil layer in clay extraction areas. Clay is used for earthworks of operational locations, access roads and landfill in many phases of the production of oil and natural gas. The use of clay as a mineral resource results in environmental degradation, with vegetation suppression or impeding its regeneration, removal of soil organic matter and also from subsurface horizons, resulting in degraded landscapes (SCHIAVO et al., 2007; SILVA et al., 2012; MECHI e SANCHES, 2010).

The soils found in clay extraction area are unfavorable for the development of species, specially the non-nitrogen fixing ones, since they have chemical, physical and microbiological characteristics that are inadequate for their development (SHIAVO et al., 2009). In an experiment developed in gravel deposits in the Caatinga used by oil extraction, Lima et al. (2015) have observed that nodulated legume tree species presented higher survival and growth rates in relation to non-nodulated ones.

In mining areas, nitrogen, phosphorous, and potassium are the three main macronutrients found in deficiency. Thus, recently mined soils need significant applications of fertilizers for the establishment and maintenance of the species to be implanted (SHEORAN et al., 2010). Silva (2018) has demonstrated that substrates of areas used by oil and natural gas activities in Caatinga have presented lower stocks of organic material, nitrogen and phosphorous when compared to soils in native areas, also evincing the importance of the use of nutrients for the development of species. Besides the low 
fertility, the clay extraction areas are extremely compacted, being necessary to use techniques that allow for the development of species.

One of the ways of recovering these clay deposits is revegetation with native species of that biome. This technique requires the selection of adequate species, which can stand the conditions of the area and accelerate the recovery of the natural succession process (SHEORAN et al., 2010; JESUS et al., 2016). Soil inversion and the application of increasing doses of NPK may favor the process of revegetation. Considering that native forest species have distinct nutritional demands and that there is a lack of studies correlating the development of these plants with chemical fertilization, it is required studies that aim to understand this relation.

Therefore, this study aimed to evaluate the influence of soil preparation and NPK levels on the growth of five Atlantic Rainforest native species in a clay extraction area.

\section{MATERIAL AND METHODS}

The study was carried out from February to September 2018, in a clay extraction area, located in Tabuleiro Costeiro area, which was used for earthmoving access roads and operating locations for oil and natural gas production in the municipality of São Mateus, ES, with around 23 meters of altitude. The soil is a Yellow Latosol, with insufficient drainage, in which the fertile superficial layer was removed at an average of 5 $\mathrm{m}$ deep, with chemical properties according to Table 1.

Table 1 - Chemical properties of the soil in the experimental area in São Mateus city, ES, at a $0-20 \mathrm{~cm}$ depth

\begin{tabular}{|c|c|c|c|c|c|c|c|c|c|c|c|}
\hline pH & MO & $\mathbf{P}$ & $\mathbf{K}$ & $\mathrm{Ca}$ & Mg & Al & $\mathbf{H}+\mathbf{A l}$ & SB & $\mathbf{T}$ & $\mathbf{v}$ & $\mathbf{M}$ \\
\hline$\left(\mathrm{H}_{2} \mathrm{O}\right)$ & $\mathrm{g} \mathrm{Kg}^{-1}$ & \multicolumn{2}{|c|}{--- $\mathrm{mg} \mathrm{dm} \mathrm{dm}^{-3}$--- } & \multicolumn{6}{|c|}{ - } & \multicolumn{2}{|c|}{------ \% ------ } \\
\hline 4,60 & 4,73 & 0,69 & 8,75 & 0,26 & 0,21 & 0,68 & 2,20 & 0,59 & 2,79 & 20,45 & 55,42 \\
\hline
\end{tabular}

The climate of the region is of the Aw type, according to the international Köppen classification, tropical and humid with dry winter and rainy summers (ALVARES et al., 2014). Daily rainfall and maximum, minimum and average temperature data from April to 
September 2018 were collected by the Davis 6162 Wireless Vantage Pro2 Plus weather station model, 1400 meters from the experimental area (Figure 1).

Figure 1 - Rainfall $(\mathrm{mm})$ and maximum and minimum temperatures $\left({ }^{\circ} \mathrm{C}\right)$ daily, from April to September, 2018, for characterization of the experimental area

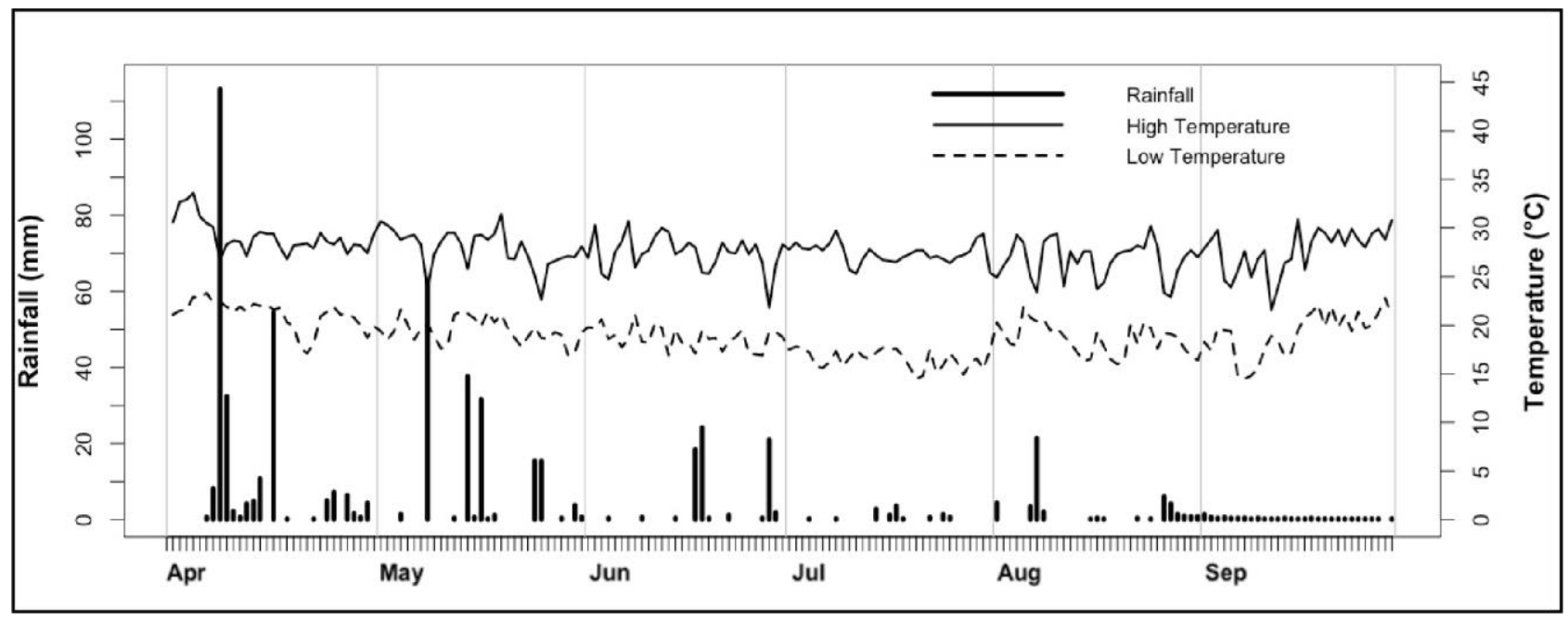

The experimental design was randomized block in a split-split plot arrangement with four replications. Subsoiling and scarification soil preparation represented main plots. Doses of NPK 04-14-08: 0; 40; 80;160; and $320 \mathrm{~g}$ pit-1 represented subplots and Atlantic Rainforest native species represented sub-subplots (Table 2), in a total of 50 treatments.

The eight parts were each $10 \times 10 \mathrm{~m}$ wide. Subparts, a total of 40, were $2 \times 10 \mathrm{~m}$ and contained each 25 plants. Sub-subparts, a total of 200, were $2 \times 2 \mathrm{~m}$ and had each five plants. A total of 1000 plants was cultivated.

Table 2 - Main characteristics of the species used to recover the clay extraction area

\begin{tabular}{lcc}
\hline Species & Family & Ecological Group \\
\hline Dalbergia ecastaphyllum & Fabaceae & Pioneer \\
Inga laurina & Fabaceae & Non-Pioneer \\
Protium heptaphyllum & Burseraceae & Non-Pioneer \\
Psidium cattleyanum & Myrtaceae & Non-Pioneer \\
Schinus terebinthifolius & Anacardiaceae & Pioneer \\
\hline
\end{tabular}

Source: IEMA (2018); SOUZA (2010); SCOLFORO et al. (2008) 
Soil preparation was carried out a month before planting seedlings, performing the scarification with a scarifier containing three curved rods, working at a $25 \mathrm{~cm}$ depth, and the subsoiling with a subsoiler containing also three curved rods at a $70 \mathrm{~cm}$ depth, with later passage of three light grates to uniformize the area. After preparing the soil, the correction of $\mathrm{pH}$ was performed, increasing base saturation to $70 \%$, with the application of limestone and later incorporation with grate. The clay extraction area was then revegetated with the planting of five facilitating species previously described, in a quincunx pattern with $1 \mathrm{~m}$ space between peripheral plants and $2 \mathrm{~m}$ between central ones, in pits of $0.40 \times 0.40 \times 0.40 \mathrm{~m}$. Seedlings were acquired in a RENASEM accredited nursery in the region of São Mateus, ES. After transplantation, the seedlings were irrigated three times for week in first month, twice in second and once a week in the third month. The irrigation was with $2 \mathrm{~L}$ of water per plant per application. Seedlings received coverage fertilization at each 60 days with the application of 25 grams per plant of the formulate NPK 20-00-20 Micro Totalß.

The experiment was carried out for 210 days and morphological characteristics were evaluated. Plant height was determined from soil level to the plant's peak, with the help of a measuring tape divided in millimeters, stem diameter was measured at the soil level with the help of a digital pachymeter with millimetric precision and number of leaves was assessed for direct quantification. The absolute growth rate of the species was calculated according to Reis and Muller (1979) (1):

$$
\mathrm{AGR}=\frac{\mathrm{H} 2-\mathrm{H} 1}{\mathrm{~T} 2-\mathrm{T} 1}
$$

In which: $\mathrm{H} 1$ and $\mathrm{H} 2$ represent the variation in the plant's height in two consecutive samples measured in $\mathrm{T} 1$ and $\mathrm{T} 2$ times, $\mathrm{cm}$ month $^{-1}$.

The statistical analysis of the results was performed by the software R (R CORE TEAM, 2018). The $F$ test was used at $5 \%$ for variance analysis. In significant cases, the Tukey test was used for qualitative factors and linear, quadratic and square root regressions for quantitative factors. The choice for the equation that better adjusted to the data of the quantitative factor was determined by the $F$ test $p<0.05$ and the R2 determination coefficient was adjusted to the treatment average. The results were presented and discussed in two phases. In the first, the comparison among species in each NPK fertilization dose applied was considered. In the second, the individual result of each species in relation to the increase in doses was evaluated. 


\section{RESULTS AND DISCUSSION}

The results of the average square of absolute growth rate, stem diameter and number of leaves in clay extraction area are presented in Table 3. It was verified that the development of the plants was not affected by the kind of soil preparation and dose factors, species and the dose $x$ species interaction were significant by the $F$ test at $5 \%$ significance.

Table 3 - Summary of the variance analysis of the absolute growth rate (AGR), stem diameter (SD), and number of leaves (NL) of the experiment in clay extraction area, 210 days after planting

\begin{tabular}{|c|c|c|c|c|}
\hline \multirow{2}{*}{ Variance Source } & \multirow{2}{*}{ DF } & \multicolumn{3}{|c|}{ Mean Square } \\
\hline & & AGR & SD & NL \\
\hline Block & 3 & $11.88^{\text {ns }}$ & $50.76^{\mathrm{ns}}$ & $19645^{\mathrm{ns}}$ \\
\hline Preparation & 1 & $1.56 \mathrm{~ns}$ & $22.43^{\text {ns }}$ & $151^{\mathrm{ns}}$ \\
\hline Residue a & 3 & 12.68 & 41.14 & 11343 \\
\hline Dose & 4 & $137.55^{*}$ & $254.33 *$ & 111687* \\
\hline Preparation:Dose & 4 & $6.74 \mathrm{~ns}$ & $8.37^{\mathrm{ns}}$ & $2027^{\text {ns }}$ \\
\hline Residue $b$ & 24 & 9.88 & 12.49 & 9129 \\
\hline Species & 4 & $1661.40 *$ & $1350.40 *$ & $296819 *$ \\
\hline Preparation:Species & 4 & $5.70 \mathrm{~ns}$ & $10.70^{\text {ns }}$ & $1464^{\text {ns }}$ \\
\hline Dose:Species & 16 & $26.80 *$ & $50.10 *$ & $31142 *$ \\
\hline Preparation:Dose:Species & 16 & $9.30 \mathrm{~ns}$ & $11.40^{\text {ns }}$ & $9264^{\text {ns }}$ \\
\hline Resíduo c & 120 & 12.10 & 8.20 & 7778 \\
\hline CV\% (Preparation) & & 44.03 & 43.05 & 70.80 \\
\hline CV\% (Dose) & & 38.85 & 23.71 & 63.51 \\
\hline CV\% (Species) & & 43.02 & 19.16 & 58.62 \\
\hline
\end{tabular}

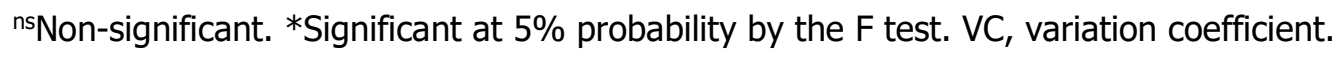




\subsection{First phase}

The highest absolute growth rate, in all evaluated doses, was observed for Dalbergia ecastaphyllum (Table 4). The superiority of this species in relation to the others may be related to the fact that it is a leguminous plant of the ecological group of pioneers (CAMARGO et al., 2009). Leguminous trees have a mutualistic relation to bacteria of the Rhizobium genus, which fixate nitrogen in nodules, making it available for the plant (SOUZA e CAPELLARI JUNIOR, 2004; LARCHER, 1986; TAIZ et al., 2017). Nitrogen is an essential element, with positive effects for plant growth, participating as the constituent of enzymes, proteins, chlorophyll molecules, cytochromes, nucleic acids, among others (MARCHNER, 1995; MALAVOLTA, 2006).

For the Schinus terebinthifolius specie, also belonging to the pioneer ecological group, it was observed that its behavior at 0 dose was similar to the one by Inga laurina, Protium heptaphyllum and Psydium cattleyanum, which are non-pioneer species. However, with the increase in planting fertilization, this species has presented a growth higher than the other non-pioneer ones, reaching a superior growth rate at the $320 \mathrm{~g}$ pit-1 (Table 4), which indicates it is highly responsive to fertilization and that it has great potential for the revegetation of the area. However, considering the Caatinga biome, Lima et al. (2015), when studying the growth of nodulated and non-nodulated species in area degraded by gravel mining, have observed low growth and survival rates for $\mathrm{S}$. terebinthifolius. It is important to highlight that the authors have performed planting fertilization with 2 liters of solid cattle manure, 40 grams of simple superphosphate and 10 grams of FTE BR15 and cultivated the plants without irrigation.

Table 4 - Average absolute growth rate (cm month-1) of the species, when cultivated under increasing doses of NPK 04-14-08 in clay extraction area, 210 days after planting

\begin{tabular}{|c|c|c|c|c|c|c|}
\hline \multirow{2}{*}{ Species } & \multicolumn{6}{|c|}{ Doses of NPK 04-14-08 $\left(\mathrm{g} \mathrm{pit}^{-1}\right)$} \\
\hline & $\mathbf{0}$ & 40 & 80 & 160 & 320 & Average \\
\hline Dalbergia ecastaphyllum & $10.94 \mathrm{a}$ & $19.37 \mathrm{a}$ & $19.73 \mathrm{a}$ & $23.03 \mathrm{a}$ & $18.86 \mathrm{a}$ & 18.39 \\
\hline Inga laurina & $4.53 \mathrm{~b}$ & $5.71 \mathrm{bc}$ & $6.65 \mathrm{~b}$ & $7.79 \mathrm{bc}$ & $5.89 \mathrm{c}$ & 6.11 \\
\hline Protium heptaphyllum & $3.02 b$ & $3.91 \mathrm{c}$ & $4.69 \mathrm{bc}$ & $5.55 \mathrm{~cd}$ & $4.66 \mathrm{c}$ & 4.37 \\
\hline Psidium cattleyanum & $1.24 \mathrm{~b}$ & $1.77 \mathrm{c}$ & $1.80 \mathrm{c}$ & $2.09 \mathrm{~d}$ & $2.10 \mathrm{c}$ & 1.80 \\
\hline Schinus terebinthifolius & $5.53 b$ & $9.29 \mathrm{~b}$ & $9.29 \mathrm{~b}$ & $11.67 \mathrm{~b}$ & $\begin{array}{c}12.99 \\
\mathrm{~b}\end{array}$ & 9.75 \\
\hline Average & 5.05 & 8.01 & 8.43 & 10.02 & 8.90 & \\
\hline
\end{tabular}

Averages followed by the same letter in the column are similar at $5 \%$ of probability by the Tukey Test. 
Regarding the average values of species' stem diameter, in the doses of 40 and 80 g pit-1, D. ecastaphyllum stood out from the others (Table 5). For doses of 0, 160, and $320 \mathrm{~g}$ pit-1, it did not differ from S. terebinthifolius. For Souza et al. (2006) and Carneiro (1983), the stem diameter is important for growth and for the survival potential after planting, considering that wider diameters provide better capacity for root formation and growth. In an area degraded by the extraction of sand, Souza et al. (2001) have observed S. terebinthifolius plants with stem diameters of $11.0 \mathrm{~mm}$ six months after planting. A wider diameter than that, 210 days after planting, was observed in this study $(25.87 \mathrm{~mm})$ with the application of $320 \mathrm{~g}$ pit-1 of NPK 04-14-08 (Table 5).

Table 5 - Average stem diameter $(\mathrm{mm})$ for species cultivated under increasing doses of NPK 04-14-08 in clay extraction area, 210 days after planting

\begin{tabular}{lcccccc}
\hline \multirow{2}{*}{ Species } & \multicolumn{7}{c}{ Doses of NPK 04-14-08 } \\
\cline { 2 - 8 } & $\mathbf{0}$ & $\mathbf{4 0}$ & $\mathbf{8 0}$ & $\mathbf{1 6 0}$ & $\mathbf{3 2 0}$ & Average \\
\hline Dalbergia ecastaphyllum & $15.01 \mathrm{a}$ & 22.53 & $24.74 \mathrm{a}$ & $26.29 \mathrm{a}$ & $24.43 \mathrm{a}$ & 22.60 \\
Inga laurina & $9.36 \mathrm{~b}$ & $13.67 \mathrm{bc}$ & $14.37 \mathrm{c}$ & $14.04 \mathrm{~b}$ & $13.68 \mathrm{~b}$ & 13.02 \\
Protium heptaphyllum & $8.20 \mathrm{~b}$ & $8.40 \mathrm{~d}$ & $9.65 \mathrm{~d}$ & $9.36 \mathrm{c}$ & $8.82 \mathrm{c}$ & 8.89 \\
Psidium cattleyanum & $9.83 \mathrm{~b}$ & $10.51 \mathrm{~cd}$ & $11.54 \mathrm{~cd}$ & $11.65 \mathrm{bc}$ & $10.15 \mathrm{bc}$ & 10.74 \\
Schinus terebinthifolius & $11.23 \mathrm{ab}$ & 16.64 & $19.75 \mathrm{~b}$ & $22.66 \mathrm{a}$ & $25.87 \mathrm{a}$ & 19.23 \\
\hline Average & 10.72 & 14.35 & 16.01 & 16.80 & 16.59 & \\
\hline
\end{tabular}

Averages followed by the same letter in the column are similar at $5 \%$ probability by the Tukey test.

The species that presented higher numbers of leaves when fertilized during planting were D. ecastaphyllum and S. terebinthifolius (Table 6). Since they are pioneer species, they have accelerated growth and development for a short time, providing the development conditions for non-pioneer species due to the shade offered to them. Pioneer species differed significantly in the number of leaves only when planting fertilization was performed, showing that the fertilization favors the appearance of new leaves and, consequently, increases the plants' photosynthetically active area. 
Table 6 - Average number of leaves of species when cultivated under increasing doses of NPK 04-14-08 in clay extraction area, 210 days after planting

\begin{tabular}{|c|c|c|c|c|c|c|}
\hline \multirow{2}{*}{ Species } & \multicolumn{5}{|c|}{ Doses of NPK 04-14-08 $\left(\mathrm{g} \mathrm{pit}^{-1}\right)$} & \multirow[b]{2}{*}{ Average } \\
\hline & $\mathbf{0}$ & 40 & 80 & 160 & 320 & \\
\hline Dalbergia ecastaphyllum & $110.8 \mathrm{a}$ & $231.2 \mathrm{a}$ & $291.5 \mathrm{a}$ & $305.0 \mathrm{a}$ & $361.6 \mathrm{a}$ & 260.0 \\
\hline Inga laurina & $34.6 \mathrm{a}$ & $47.6 \mathrm{~b}$ & $65.8 \mathrm{~b}$ & $63.1 \mathrm{~b}$ & $75.8 \mathrm{~b}$ & 57.4 \\
\hline Protium heptaphyllum & $76.3 \mathrm{a}$ & $83.1 \mathrm{~b}$ & $110.8 b$ & $94.0 \mathrm{~b}$ & $111.1 \mathrm{~b}$ & 95.1 \\
\hline Psidium cattleyanum & $104.6 \mathrm{a}$ & $105.7 \mathrm{~b}$ & $124.8 \mathrm{~b}$ & $150.6 \mathrm{~b}$ & $108.0 \mathrm{~b}$ & 118.7 \\
\hline Schinus terebinthifolius & $73.1 \mathrm{a}$ & $121.0 \mathrm{ab}$ & $172.0 \mathrm{ab}$ & $362.6 \mathrm{a}$ & $375.2 \mathrm{a}$ & 220.8 \\
\hline Average & 79.9 & 117.7 & 153.0 & 195.1 & 206.3 & \\
\hline
\end{tabular}

Averages followed by the same letter in the column are similar at $5 \%$ probability by the Tukey test.

\subsection{Second phase}

Regression models were adjusted for the absolute growth rate of all species evaluated, as a function of NPK 04-14-08 doses applied at planting (Figure 2). For D. ecastaphyllum and $P$. cattleyanum species, the square root model best explained the growth rate results (Figure $2 \mathrm{~A}$ and $2 \mathrm{D}$ ). The coefficient of determination found for these species were 0.9560 and 0.9965 , respectively, indicating a high correlation between NPK levels applied at planting and the growth rate of these species. The equation $\hat{y}=$ $10.81142+1.80115 \mathrm{~d} 0.5-0.07434 \mathrm{~d}$ was adjusted for $\mathrm{D}$. ecastaphyllum, estimating its maximum growth rate of $21.72 \mathrm{~cm}$ month-1 with $146.75 \mathrm{~g}$ pit-1 of NPK 04-14-08 application. The species P. cattleyanum with equation adjustment $\hat{y}=1.2411470+$ $0.0953381 \mathrm{~d} 0.5+0.0025897 \mathrm{~d}$, allows its maximum growth rate $(2.11 \mathrm{~cm}$ month- 1$)$ to be obtained with the dose of $320 \mathrm{~g}$ pit-1 of NPK at planting, because the maximum point found was estimated by an out-of-curve value.

For the species I. laurina and P. heptaphyllum, the second degree polynomial model allowed the best adjustment of the absolute growth rate results of these species (Figure 2B and 2C). Both have shown a correlation coefficient considered as high, 0.9970 and 0.9992, respectively, having a strong correlation between NPK levels and the species' growth rate. According to the equation $\hat{y}=4.4753+0.0360 d-0.00009867 d 2$, the maximum growth rate of $7.76 \mathrm{~cm}$ month-1 would be reached with the application of $182.43 \mathrm{~g}$ pit-1 of NPK 04-14-08 for I. laurina. While for P. heptaphyllum, the equation $\hat{y}=$ $2.9986+0.0265 d-0.0000665 d 2$ estimates a maximum growth rate of $5.64 \mathrm{~cm}$ month-1 with the application of $199.25 \mathrm{~g}$ pit-1 of NPK during planting. 
The effect of NPK fertilization during planting on the growth rate of S. terebinthifolius was crescent linear, varying the minimum and maximum estimated values between 7.35 and $13.77 \mathrm{~cm}$ month-1, which corresponds to $87.35 \%$ increase, showing the importance of applying macronutrients for the initial growth of this species. The determination coefficient of 0.7974 indicates that $79.74 \%$ of the variation of the growth rate is explained by the linear equation $\hat{y}=7.3465+0.02009 d$ (Figure 2E). Scheer et al. (2017), when evaluating two-years old S. terebinthifolius in an area degrade due to clay extraction, have observed an average plant height of $2.52 \mathrm{~m}$. Considering this height and the plant's age, it is possible to estimate an absolute growth rate of only $0.09 \mathrm{~cm}$ month-1 when applying $500 \mathrm{~g}$ pit-1 of NPK 05-20-10 and of limestone. Vieira et al. (2017), when testing increasing levels of NPK in the planting of Tectona grandis, with six months on field, have concluded that nitrogen and phosphorous are needed since the planting of the species, while the plant's demand for potassium begins after that period.

NPK formulation is constituted by percentages of the nitrogen, phosphorous, and potassium nutrients, respectively. Nitrogen is one of the most demanded elements by plants, and the one that limits growth the most. Its deficiency results on gradual chlorosis of older leaves and on the reduction of growth (SOUZA e FERNANDES, 2006). Phosphorus participates in various plant metabolic processes such as energy transfer, nucleic acid synthesis, glucose and respiration, and is closely linked to root growth. Therefore, it is added only at planting. Its deficiency also limits plant growth (ARAUJO e MACHADO, 2006). Potassium is the most abundant cation on plants, being absorbed in great amounts by the roots. It has an important role on the energetic status, on assimilate translocation and storage, and on the maintenance of water in vegetal tissues (MEURER, 2006). These three macronutrients are the basis of plant fertilization and are used for implantation and maintenance of many cultures, having, generally, NPK applied during planting and NK during coverage.

The stem diameter of the species in relation to the fertilization with NPK 04-14-08 during planting are presented in Figure 3. Model adjustment was not possible for P. heptaphyllum species alone, with a mean of $8.89 \mathrm{~mm}$ (Table 5). D. ecastaphyllum and I. laurina presented square root model fit (Figure $3 A$ and $3 B$ ), with equation $\hat{y}=14,892124$ $+1,660298 \mathrm{~d} 0,5-0,062488 \mathrm{~d}$ and coefficient of determination of 0.9958 , allowing maximum estimation of stem diameter $(25.92 \mathrm{~mm})$ with application of $176.49 \mathrm{~g}$ pit-1 NPK 04-14-08 at planting for D. ecastaphyllum. While for I. laurina, the equation $\hat{y}=9.477702$ $+0.831905 \mathrm{~d} 0.5-0.033942 \mathrm{~d}$ was adjusted, with a coefficient of determination of 0.9750 , 
allowing to obtain the maximum stem diameter $(14.57 \mathrm{~mm})$ with the application of 150.18 g pit-1 of NPK. According to Souza et al. (2006) plants with high stem diameter have higher resistance to adverse environmental conditions.

Figure 2 - Effect of doses of NPK 04-14-08 on the absolute growth rate of Dalbergia ecastaphyllum (A), Inga laurina (B), Protium heptaphyllum (C), Psidium cattleyanum (D) and Schinus terebinthifolius $(\mathrm{E})$ in clay extraction area, 210 days after planting

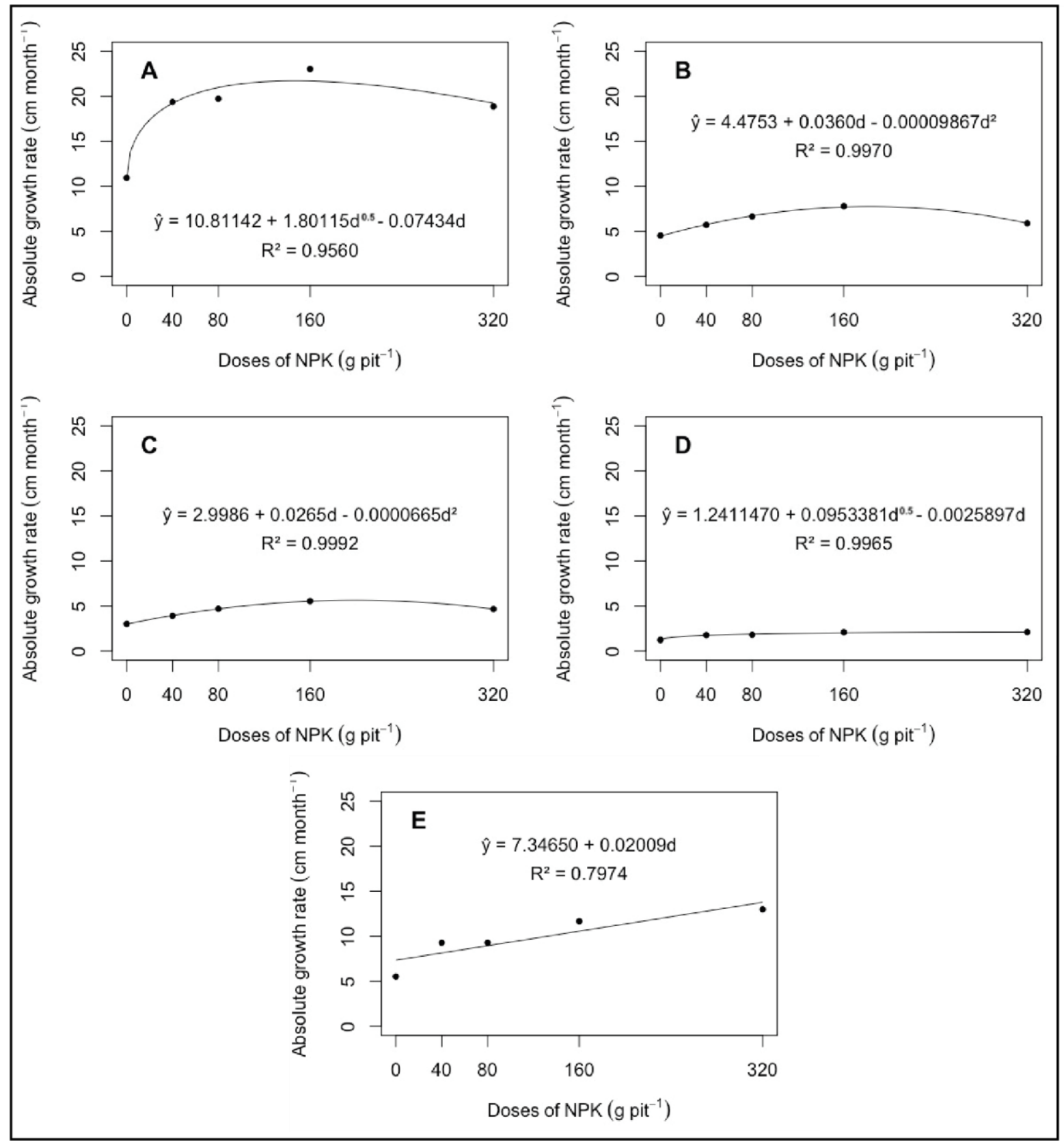


By analyzing the effect of fertilization during planting on the stem diameter of $\mathrm{P}$. cattleyanum through regression, it was verified that the second degree polynomial model was the one that better adjusted to the data (Figure 3C). It was observed that the widest stem diameter, $11.79 \mathrm{~mm}$, was obtained with the application of $166.48 \mathrm{~g} \mathrm{pit}^{-1}$ of NPK 04$14-08$, values estimated by the equation $\hat{y}=9.8451+0.02338 \mathrm{~d}-0.00007022 \mathrm{~d}^{2}$, which explains $95.62 \%$ of the stem diameter behavior in relation to the variation of NPK doses during planting.

For S. terebinthifolius, the stem diameter in relation to NPK doses applied during planting also presented crescent linear adjustment (Figure 3D), as well as for growth rate, placing itself as a species highly responsive to fertilization during planting. The estimated equation $\hat{y}=14.3437+0.04077 d$ shows us a variation from 14.34 to $27.39 \mathrm{~mm}$ between 0 and 320 doses, respectively. This variation represents a $91 \%$ range in stem diameter, with $84.00 \%$ (R2) of this variation being explained by the equation. Souza et al. (2006), when working with S. terebinthifolius in Dystrophic Red Latosol, with the use of organic fertilizers and NPK 20-05-15 in the $75 \mathrm{~g}$ pit-1 dose, have observed stem diameters from $6.80 \mathrm{~mm}$ to $9.40 \mathrm{~mm} 120$ days after planting. When analyzing the initial growth of Tectona grandis, Vieira et al. (2017) have observed wider stem diameters at six months old when NPK fertilization was carried out during planting. The authors also reported that, during this period, fertilizers were in the phase of maximum liberation of nutrients, thus favoring its availability and absorption by the plants.

The stem diameter measure portrays the plant's secondary growth while still young, and it is a reference to the diameter at breast height (DBH), used in dendrometry for adult trees. Diameter at breast height (DBH) is the most important element measured in a tree, since it provides the basis for many other calculations. However, it cannot be used for young trees, since it works for the obtention of the sectional area at breast height, 1.30 $\mathrm{m}$, in relation to the soil, an important measure for the calculation of tree volume and population. Grouping tree diameters into classes (DBH classes) defines the diametric distribution of the forest, which is essential for the definition of the growth stock for the analysis of economic and silvicultural decisions (LOETSCH et al., 1973). 
Figure 3 - Effect of doses of NPK 04-14-08 on the stem diameter of Dalbergia ecastaphyllum (A), Inga laurina (B), Psidium cattleyanum (C) e Schinus terebinthifolius (D) in clay extraction area, 210 days after planting

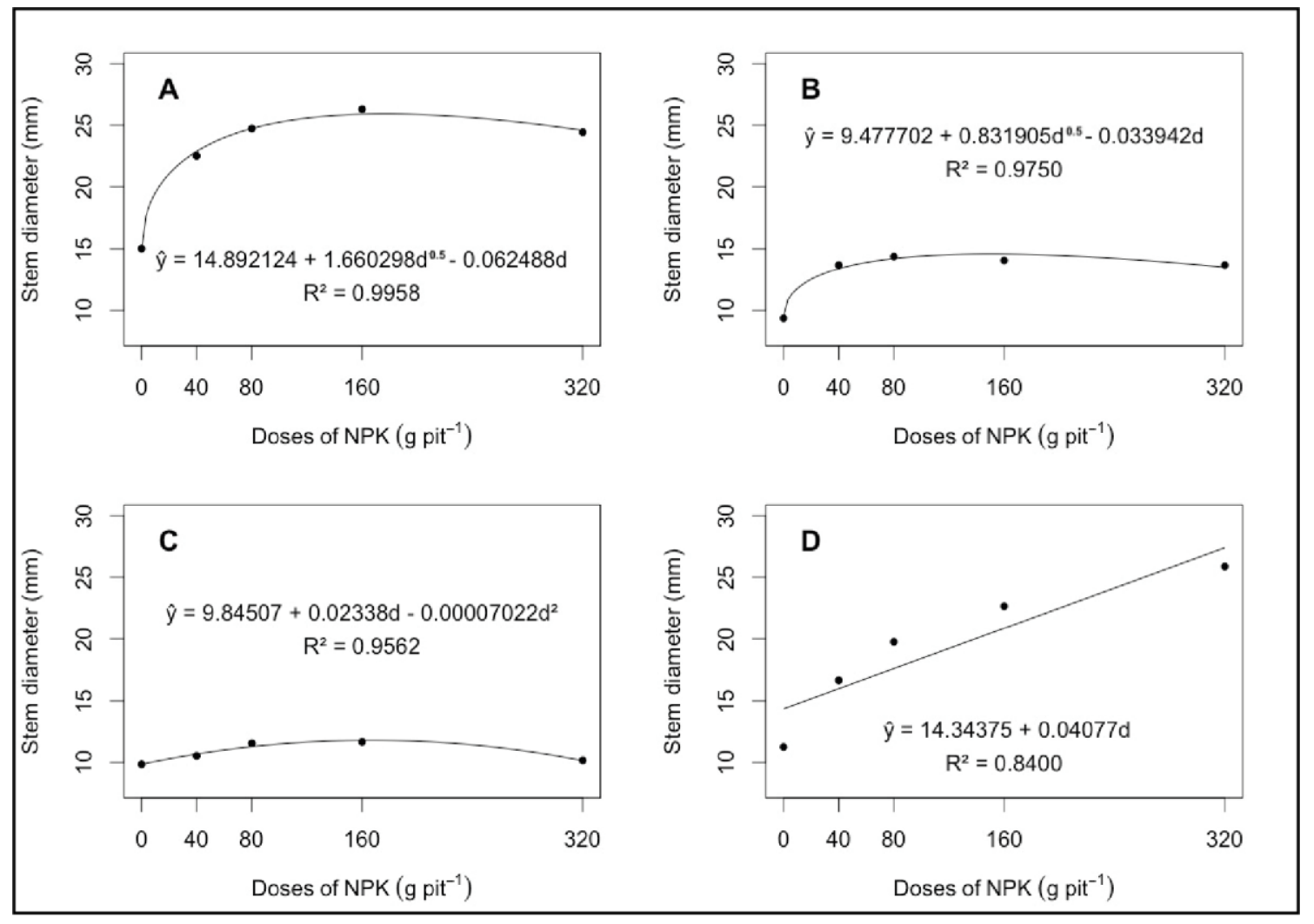

The effect of NPK doses at planting on leaf number allowed the adjustment of equation models only for D. ecastaphyllum and S. terebinthifolius (Figure 4). The other species, I. laurina, P. heptaphyllum and P. cattleyanum presented average number of leaves of 57.4, 95.1 and 118.7, respectively (Table 6).

For $D$. ecastaphyllum, the square root model best explained the number of leaves of this species (Figure $4 \mathrm{~A}$ ). By the equation $\hat{y}=111.7553+22.8266 \mathrm{~d} 0.5-0.5069 \mathrm{~d}$ and coefficient of determination of 0.9862 , it was found that the maximum number of leaves (357 leaves) can be achieved by applying $320 \mathrm{~g}$ pit-1 of NPK 04-14-08. It is noteworthy that the species D. ecastaphyllum showed high lateral branching, leading to a visually superior biomass production of non-pioneer species. This branching provides shading that benefits the early development of non-pioneer species (GALVÃO e MEDEIROS, 2002). Acclimatization, which is the vegetal characteristic of movement plasticity to respond to different light regimes, is important for these species. When plants are exposed to a higher amount of light than they can use, the reaction center of the photosystem II is inactivated by photoinhibition, compromising vegetal development (TAIZ et al., 2017). 
The species S. terebinthifolius presented increasing linear regression adjustment (Figure 4B). Without fertilization at planting, the species reaches 100 leaves, but when applying $320 \mathrm{~g}$ pit-1 NPK $04-14-08$ this average increase by $321 \%$, rising to 421 leaves, according to the estimated equation $\hat{y}=100.39+1.003 \mathrm{~d}$ and coefficient of determination of 0.8249 . This increase demonstrates plants with greater aptitude for field conditions, as they have a larger photosynthetically active area (MELO et al., 2007).

D. ecastaphyllum presented equation adjustment by square root model for all morphological variables analyzed, showing that these variables increase to a maximum point in response to planting fertilization levels, and decrease when very high doses. According to Pereira et al. (2013) Rhizobium nodule density in D. ecastaphyllum roots decreases with increasing soil fertility. The increase of NPK doses may have caused a decrease in Rhizobium nodule density, which limited the growth of the species in high doses of fertilization. When revegetating an area degraded by bauxite washing, with different leguminous and non-leguminous tree species, Franco et al. (2006) have observed that, after 22 months, leguminous species that performed biological nitrogen fixation had higher biomass production and growth than other species, evincing the capacity of developing themselves in areas with low fertility. Satisfactory results using leguminous trees for revegetation of areas degraded by superficial horizon removal were obtained by Franco et al. (1995) and Macedo et al. (2008) in the Southeast region, and by Lima et al. (2015) in the Northeast of Brazil.

Figure 4 - Effect of doses of NPK 04-14-08 on the number of leaves of Dalbergia ecastaphyllum (A) e Schinus terebinthifolius (B) in clay extraction area, 210 days after planting
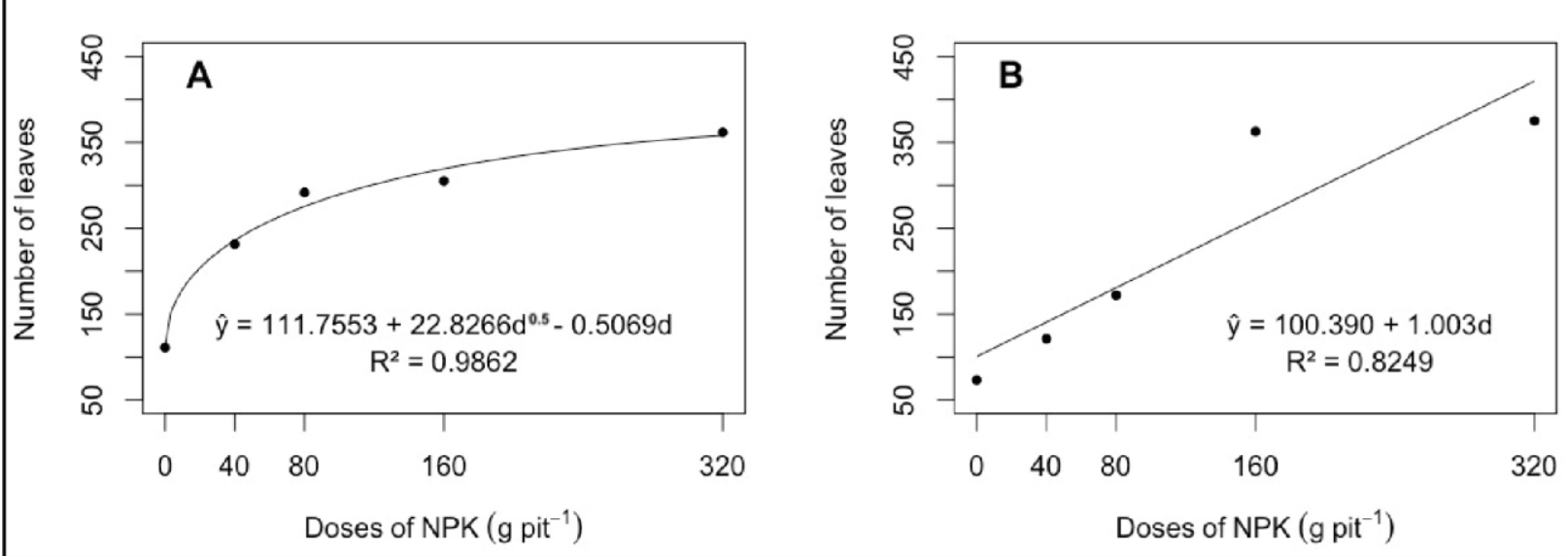
Although the levels of NPK tested did not influence the stem diameter of the Protium heptaphyllum and the number of leaves of the species Inga laurina, Protium heptaphyllum and Psidium cattleyanum. The growth rate of the species was sensitive to the increase of NPK dose applied at planting (Figure 2B, 2C and 2D). Schinus terebinthifolius is highly demanding in planting fertilization, considering that the maximum dose of NPK 04-14-08 tested did not completely meet the need for the species. Linear behavior was observed for all morphological characteristics analyzed, and higher dose tests will recommend for this species. Tabaldi et al. (2016), when working with the production of biomass, and phenolic and flavonoid contents of Schinus terebinthifolius cultivated with poultry manure, have also observed increasing linear responses for the characteristics assessed.

Pioneer species used, Dalbergia ecastaphyllum and Schinus terebinthifolius, have had higher levels than the other in all analyzed variables, in most of the doses, while the lowest growth rate, stem diameter, and number of leaves averages were observed in nonpioneer species, Inga laurina, Protium heptaphyllum and Psidium cattleyanum. According to Lima et al. (2015), the slow growth of a certain species can be related to the species' intrinsic characteristics and not to the limitations of the environment it is placed. The use of species with different growth and development characteristics is important for secondary succession and for the forest's heterogeneity. The Dalbergia ecastaphyllum, Schinus terebinthifolius and Psidium cattleyanum species are recommended for restoration projects in restinga by Rodrigues et al. (2016). Bona et al. (2011), when working at a soil contaminated with diesel oil at the concentration of $92.4 \mathrm{ml}$ per soil $\mathrm{kg}$, have observed that $\mathrm{S}$. terebinthifolius germination is no longer affected after 30 days of contamination, being thus recommended as a potential species for phytoremediation in soils with oil hydrocarbons.

\section{CONCLUSIONS}

The type of soil preparation used did not affect the development of the species in clay extraction area.

Pioneer species, Dalbergia ecastaphyllum and Schinus terebinthifolius stood out from the others in most doses of NPK evaluated. 
Although non-pioneers have presented slow growth, they are important for secondary succession and should be recommended for revegetation in degraded areas.

For the planting of Dalbergia ecastaphyllum, Inga laurina, Protium heptaphyllum and Psidium cattleyanum in areas degraded by clay extraction, it is recommended the application of $176.49,150.18,199.25$, and $166.48 \mathrm{~g}$ pit-1 of NPK 04-14-08 during planting, respectively.

Schinus terebinthifolius was highly responsive to planting fertilization, being recommended the dose of $320 \mathrm{~g}$ pit-1 of NPK 04-14-08. However, tests with higher doses are necessary to determine a great point of development for that species.

\section{ACKNOWLEDGEMENT}

To the Environment management of the Petrobras Researches Center (CENPES) for the technical and financial support to the research.

\section{REFERENCES}

ALVARES CA, STAPE JL, SENTELHAS PC, GONÇALVES JLM, SPAROVEK G. Koppen's climate classification map for Brazil. Meteorologische Zeitschrift. 2014; 22 (6): 711-728.

ARAÚJO AP, MACHADO CTT. Fósforo. In: FERNANDES MS, editor. Nutrição mineral de plantas. Viçosa: Sociedade Brasileira de Ciência do Solo; 2006. p.253-280.

BONA C, REZENDE IM, SANTOS GO, SOUZA LA. Effect of soil contaminated by diesel oil on the germination of seeds and the growth of Schinus terebinthifolius Raddi (Anacardiaceae) Seedlings. Brazilian Archives of Biology and Technology. 2011;54(6):1379-1387.

CAMARGO TCC, NOVAES LL, MAGENTA MAG, MOURA C, PASTORE JA. Caracterização do estágio sucessional da vegetação da restinga da Vila Barra do Una, Peruíbe - SP. In: 3 Seminário de iniciação científica do Instituto Florestal. Anais...; São Paulo: Instituto Florestal Série Registros, 2009; 40, p.83-7.

CARNEIRO JGA. Influência dos fatores ambientais e das técnicas de produção sobre o desenvolvimento de mudas florestais e a importância dos parâmetros que definem sua qualidade. In: Simpósio Sobre Florestas Plantadas Nos Neotrópicos Como Fonte De Energia. Anais... Viçosa: Universidade Federal de Viçosa, 1983. p.10-24.

FRANCO AA, CAMPELLO EFC, FARIA SM, DIAS LE. Revegetação de áreas degradadas pela mineração e processamento de bauxita. In: Alba JMF, editors. Recuperação de áreas mineradas: a visão dos especialistas brasileiros. Embrapa Clima Temperado. 2006. 
FRANCO AA, DIAS LE, FARIA SM, CAMPELLO EFC, SILVA EMR. Uso de leguminosas florestais noduladas e micorrizadas como agentes de recuperação e manutenção da vida do solo: um modelo tecnológico. In: ESTEVES FA, editor. Oecologia brasiliensis: estrutura, funcionamento e manejo de ecossitemas brasileiros. Piracicaba: ESALQ, 1995. p.459-467.

GALVÃO APM, MEDEIROS ACS. A restauração da Mata Atlântica em áreas de sua primitiva ocorrência natural. Colombo: Embrapa Florestas, 2002.

INSTITUTO ESTADUAL DE MEIO AMBIENTE E RECURSOS HÍDRICOS. Lista de espécies indicadas para recuperação de áreas degradadas no estado do Espírito Santo. 2018. Available from:.

URL https://iema.es.gov.br/Media/iema/Downloads/GRN/Core/Lista\%20de\%20especies\%20nat ivas\%20recomendadas\%20para\%20restauracao.xls.

JESUS EM, SANTOS TS, RIBEIRO GT, ORGE MDR, AMORIM VO, BATISTA RCRC. Regeneração natural de espécies vegetais em jazidas revegetadas. Floresta e Ambiente, 2016; 23(2), p.191-200.

LARCHER W. Ecofisiologia vegetal. São Paulo: Editora Pedagógica e Universitária Ltda, 1986.

LIMA KDR, CHAER GM, ROWS JRC, MENDONÇA V, RESENDE AS. Seleção de espécies arbóreas para revegetação de áreas degradadas por mineração de piçarra na caatinga. Revista Caatinga, 2015; 28(1), p.203-213.

LOËTSCH F, HALLER KE, ZÖHRER F. Forest inventory. 2.ed. Munich: BLV Verlagsgesellschaft, 1973.

MACEDO MO, RESENDE AS, GARCIA PC, BODDEY RM, JANTALIA CP, URQUIAGA $S$, CAMPELLO EFC, FRANCO AA. Changes in soil $\mathrm{C}$ and $\mathrm{N}$ stocks and nutrient dynamics 13 years after recovery of degraded land using leguminous nitrogen-fixing trees. Forest Ecology and Management, 2008; 255:1516-1524

MACHADO CJS, VILANI RM, FRANCO MG, LEMOS SDC. Legislação ambiental e degradação ambiental do solo pela atividade petrolífera no Brasil. Desenvolvimento e Meio Ambiente. 2013; 28:41-55.

MALAVOLTA E. Manual de nutrição mineral de plantas. São Paulo: Ceres, 2006.

MARCHNER H. Mineral nutrition of higher plants. 2.ed. London: Academic Press, 1995.

MECHI A, SANCHES DL. Impactos ambientais da mineração no estado de São Paulo. Estudos Avançados. 2010;24(68):209-220.

MELO AS, COSTA CX, BRITO MEB, VIÉGAS PRA, SILVA JÚNIOR CD. Produção de mudas de mamoeiro em diferentes substratos e doses de fósforo. Revista Brasileira de Ciências Agrárias. 2007;2(4):257-261.

MEURER E J Potássio. In: FERNANDES MS. Nutrição mineral de plantas. Viçosa: Sociedade Brasileira de Ciência do Solo, 2006. p.281-298.

OLIVEIRA EM, SOUTO JS. Mesofauna edáfica como indicadora de áreas degradadas. Revista Verde. 2011; 6(1):01-09. 
PEREIRA T, ROSSINE F, CABRAL J, VAZ R. A fertilidade do solo afeta as relações mutualísticas entre Dalbergia ecastophyllum (Fabaceae) e bactérias fixadoras de nitrogênio? In: Prática da pesquisa em ecologia da Mata Atlântica. Anais... Universidade de São Paulo, 2013. p.1-4.

R CORE TEAM. R: A language and environment for statistical computing. R Foundation for Statistical Computing, Vienna, Austria, 2018. https://www.R-project.org/.

REIS GG, MULLER MW Análise de crescimento de plantas - mensuração do crescimento. Belém: CPATU, 1979.

REIS LL. Monitoramento da recuperação ambiental de áreas de mineração de bauxita na Floresta Nacional de Saracá-Taquera, Porto Trombetas (PA). (Thesis). Universidade Federal Rural do Rio de Janeiro, Seropédica, Rio de Janeiro, 2006. 175p.

RODRIGUES LGSM, RODRIGUES FM, VIROLI SLM. Técnicas de restauração florestal em restingas. Journal of Bioenergy and Food Science. 2016;3(1):28-35.

SCHEER MB, CARNEIRO C, BRESSAN OA, SANTOS KG. Crescimento inicial de quatro espécies florestais nativas em área degradada com diferentes níveis de calagem e de adubação. Revista Floresta. 2017;47(3):279-287.

SCHIAVO JÁ, CANELLAS LP, MARTINS MA. Revegetação de cava de extração de argila com Acacia mangium. I - Atributos químicos do solo, ácidos fúlvicos e húmicos. Revista Brasileira de Ciência do Solo. 2007; 31(5):1153-1162.

SCHIAVO JA, MARTINS MA, RODRIGUES LA. Avaliação nutricional de mudas de Acacia mangium, Sesbania virgata e Eucalyptus camaldulensis inoculadas com fungos micorrízicos, em casa-de-vegetação e em cava de extração de argila. Acta Scientiarum Agronomy. 2009; 31(4): 701-707.

SCOLFORO JR, MELLO JM, SILVA CPC. Inventário Florestal de Minas Gerais: Floresta Estacional Semidecidual e Ombrófila - Florística, Estrutura, Diversidade, Similaridade, Distribuição Diamétrica e de Altura, Volumetria, Tendencias de Crescimento e Áreas aptas para o Manejo Florestal. Lavras, MG: Editora UFLA, 2008.

SHEORAN V, SHEORAN AS, POONIA P. Soil Reclamation of Abandoned Mine Land by Revegetation: A Review. International Journal of Soil, Sediment and Water. 2010; 3(2):120.

SILVA CF, SIMÕES-ARAÚJO JL, SILVA EMR, PEREIRA MG, FREITAS MSM, SAGGIN JÚNIOR OJ, MARTINS MA. Fungos micorrízicos arbusculares e proteína do solo relacionada à glomalina em área degradada por extração de argila e revegetada com eucalipto e acácia. Ciência Florestal. 2012; 22(4):749-761.

SILVA FF. Uso de topsoil como fonte de inóculo de microrganismos simbiontes para leguminosas florestais usadas na recuperação de áreas degradadas na Caatinga. (dissertation). Rio de Janeiro. Universidade Federal Rural do Rio de Janeiro, Seropédica; 2018. 73p. 
SOUZA PA, VENTURIN N, MACEDO RLG, ALVARENGA MIN, SILVA VF. Estabelecimento de espécies arbóreas em recuperação de área degradada pela extração de areia. Cerne. $2001 ; 7(2): 43-52$.

SOUZA CAM, OLIVEIRA RB, MARTINS FILHO S, LIMA JSS. Crescimento em campo de espécies florestais em diferentes condições de adubações. Ciência Florestal.2006; 16(3):243-249.

SOUZA, P.Z. Dinâmica espaço-temporal de Dalbergia ecastaphyllum (L.) Taub. em restinga no sul do Brasil. (Dissertation). Florianópolis: Universidade Federal de Santa Catarina; 2010. 118p.

SOUZA RS, FERNANDES MS. Nitrogênio. In: FERNANDES MS, editor. Nutrição mineral de plantas. Viçosa: Sociedade Brasileira de Ciência do Solo; 2006. p.215-252.

SOUZA VC, CAPELLARI JÚNIOR L. A vegetação das dunas e restingas da Estação Ecológica Juréia-Itatins. In: MARQUES OAV, DULEBA W, editor. Estação Ecológica Juréia-Itatins. Ambiente físico, flora e fauna. Ribeirão Preto: Holos Editora; 2004. p.103-114.

TABALDI LA, VIEIRA MC, ZÁRATE NAH, FORMAGIO ASN, PILECCO M, SILVA LR, SANTOS K.P, SANTOS LAC, CARDOSO CAL. Biomass yield and flavonoid and phenol content of schinus terebinthifolius cultivated in single or double row with poultry litter. Ciência Florestal. 2016; 26(3):787-796.

TAIZ L, ZEIGER E, MØLLER IM, MURPHY A. Fisiologia e desenvolvimento vegetal. 6.ed. Porto Alegre: Artmed, 2017.

VIEIRA CR, WEBER OLS, SCARAMUZZA, JF. Influência da adubação NPK no crescimento inicial de Tectona grandis L.f. em campo. Revista Instituto Florestal. 2017; 29(1):57-69. 